DIGITAL COMMONS
@ UNIVERSITY OF SOUTH FLORIDA

Volume 1

Issue 1 Volume 1 (2011): Women's Poetry
ABO: Interactive Journal for

Women in the Arts, 1640-1830

\title{
Missing Immortality: The Case of Melesina Trench (A Neglected, Celebrated, Dismissed and Rediscovered Woman Poet of the Long Eighteenth Century)
}

Katharine Kittredge

Ithaca College, kkittredge@ithaca.edu

Follow this and additional works at: https://digitalcommons.usf.edu/abo

Part of the Dramatic Literature, Criticism and Theory Commons, Educational Methods Commons, Feminist, Gender, and Sexuality Studies Commons, and the Literature in English, British Isles Commons

\section{Recommended Citation}

Kittredge, Katharine (2011) "Missing Immortality: The Case of Melesina Trench (A Neglected, Celebrated, Dismissed and Rediscovered Woman Poet of the Long Eighteenth Century)," ABO: Interactive Journal for Women in the Arts, 1640-1830: Vol.1: Iss.1, Article 4.

http://dx.doi.org/10.5038/2157-7129.1.1.3

Available at: https://digitalcommons.usf.edu/abo/vol1/iss1/4

This Scholarship is brought to you for free and open access by Digital Commons @ University of South Florida. It has been accepted for inclusion in ABO: Interactive Journal for Women in the Arts, 1640-1830 by an authorized administrator of Digital Commons @ University of South Florida. For more information, please contact digitalcommons@usf.edu. 


\section{Missing Immortality: The Case of Melesina Trench (A Neglected, Celebrated, Dismissed and Rediscovered Woman Poet of the Long Eighteenth Century)}

\section{Keywords}

archives, literary history, Melesina Trench, recovery, women's poetry

Creative Commons License

(c) $($ ) $\Theta$

This work is licensed under a Creative Commons Attribution-No Derivative Works 3.0 License. 
Although ((A somewhat different version of this paper was delivered with the subtitle "Seven Steps to Literary Obscurity" at the Wild Irish Girls conference held at the Chawton House Research Center in July of 2006.)) she has been virtually forgotten for the last one hundred and fifty years, Anglo-Irish poet Melesina Chenevix St. George Trench (1768-1827) has much to recommend her to twenty-first century scholars. ${ }^{1}$ The sheer volume and variety of the archival holdings on Trench is astounding: there are more than two thousand personal documents housed in the Hampshire Record (Winchester, UK), including letters, journals, an unfinished autobiography, and draft manuscripts of poems, essays and novels. The New York Public Library has copies of her political pamphlets and what Stephen C. Behrendt has called "hybrid" books of her poems-books she privately assembled and printed rather than published. The Bodleian Library has all five of her published books of poetry, as well as her work on child rearing: Thoughts of a Parent on Education. The Beinecke Library owns over three hundred documents (letters, drafts of articles and poems she published in periodicals) which were preserved by her friend Mary Leadbeater. This wealth of biographical, political, and personal writing allows us to see her poetry through a lens which is rarely available to twenty-first century critics studying eighteenth-century writers.

In her recent discussion of the impact of poetic and biographical collections on the reputations of eighteenth century female poets, Chantel M. Lavoie describes how "[b]iographical collections interlope on the poetic" and how biographic prefaces "interfere" with the reception of the poems (48). In contrast, the relationship between Trench's life, her reading, and her writing is one of the most intriguing aspects of her legacy. This is perhaps best demonstrated in the many ways that Trench responds to the deaths of two of her young children. Buried in the Winchester archive, the little brown book I have called "Mourning Journal” (Hampshire MS 23M93/13) ${ }^{2}$ begins with a heart-wrenching account of the death of Trench's young son, Frederick, at the age of "two years, eight months, and five days" and goes on to record her response to the sudden loss: the letters she composes for friends and family, anecdotes from his short life, the regrets she has about her mothering, and quotes from the poems which bring her solace: Thomson's The Seasons, Young's Night Thoughts, Pope’s “Elegy to the Memory of an Unfortunate Lady,” Cuthbert Shaw's "Monody to the Memory of a Young Lady.” These are followed by Trench's own, unstructured and pain-driven compositions:

One bitter remembrance, one sorrow throws its black shade alike on our joys and woes, To which nothing brightness or darkness can bring. For which joy has no balm, and affliction no sting. There seems to be a physical, as well as a moral effect in the return of the season, the month, the day, the hour on which a beloved object is torn away from us. (57-58)

This entry is the last in the Mourning Journal, but we can trace Trench's continued response to the loss of her children (a second child, Elizabeth Melesina, called "Bessy," dies in 1816) through her moving letters and her increasingly polished poetic meditations. In his recent book, British Women Poets and the Romantic Community, Behrendt quotes extensively from Trench's poem "On the Loss of Elizabeth Melesina Trench, an Only Daughter, in Her Fifth Year," "not because [he believes] it possesses unusual literary merit but because it speaks so profoundly to the essential humanity with which the poet responded to her personal tragedy" (198). Behrendt also talks about the "great poignancy" in reading this poem alongside the earlier writing Trench had done about her daughter. For me, the most poignant moment in Trench's poetry is the sonnet 
she writes in the year following Bessy's death, when she is "beyond her first mourning"; the poem begins:

I am not envious; yet the sudden glance

Of Transport beaming from a mother's eye,

When light her daughter's airy footsteps fly

Supremely graceful in the wavy dance,

Wakes, with a start, such thoughts as slept, perchance

Lull'd to repose by the long lullaby

Of many a fond complaint and heartfelt sigh:

Again the host of keen regrets advance;

Again I paint what Bessy might have been,

Since what she was I never can portray .... (“Sonnet Written at Night”)

Having read the letters which document the tumult of her early grieving, the wistfulness of this piece is even more affecting. The poem presents an unusual testimony to not only the progress of mourning, but also to the resilience of sorrow in its evolution from "black shade" into "keen regret.”

And yet, this sonnet is not the ultimate example of Trench's using poetry to work through the events and concerns of her personal life. Around the time of Bessy's death, Trench was finishing work on her most innovative work, Laura's Dream, or, The Moonlanders which is a landmark in women's science fiction. Written two years before Mary Shelley published Frankenstein, The Moonlanders is an epic poem describing a lunar society as a pastoral utopia. Trench's "Moonlanders" are humanoids who are gestated in "maternal clay" and then excavated to begin a lifespan that starts in old age and "youths" backwards until they reach the apex of youthful maturity. The male Moonlanders have purple wings, but the females are flightless; they are mated from birth (or perhaps we should say, "exhumation”) and are also united in the afterlife. When a Moonland couple decides it is time for them to "leave this world," that is what they literally do - they go to the top of a mountain; the female kneels in prayer; the male blesses her; she finally sprouts her own purple wings, and then they both fly off to the next sphere of existence.

This poem makes Trench the first woman to employ the conventions and traditions of the "lunar voyage" genre - a tradition which is most prominently represented by astronomer Johannes Kepler’s “lunar geography,” Somnium, Sive Astronima Lunaris published in 1634. Trench adapted this antiquated genre to address the issues that were most pressing in her own life: the travails of yearly child-bearing, the deaths of her young children, and the physical effects of aging. In her poem, pregnancy and childbirth are eliminated from the life cycle, and her attractive Moonlander male, Aurelio, rejects the young and lovely earthling narrator (Laura) in favor of an elderly woman described as a creature of "caducity and dire decay" who nonetheless possesses a "translucent" soul and an "angelic" mind. The Moonlanders is fascinating for its inventiveness, and for the way that Trench makes such an erudite genre serve her emotional needs. Although the poem did not sell well during Trench's life, today it holds considerable interest for scholars working on the history of science fiction and on women's literary history and is available in a variety of on-line and print formats. 
So, given all that can be gained from studying the work of Trench-her clearly written, gripping emotional accounts of private tragedy, her poignant poetry, and her playful experiments in surprising genres - it may seem strange that her writing has gone unrecognized for so long. At first glance she may seem like just one among many early modern female authors whose work was excluded from the male-dominated literary canon, but a closer look at the actual history of the reception of Trench's work reveals a case history that was shaped more by circumstances that were unusual if not unique. Unlike many of the women writers from her generation, Trench authored a volume which was a mid-Victorian best-seller. When the collection of her works, The Remains of the Late Mrs. Richard Trench, was published in 1862, it received rave reviews and was expected to gain, as Richard Monckton Milnes writes in The Edinburgh Review, "a high and lasting repute" ("The Remains of the Late" 129). And yet, fifty years later, Trench had virtually vanished from the public eye. The story of how this obscure eighteenth century writer came to be celebrated in the nineteenth century, forgotten in the twentieth century, and is now being rediscovered in the twenty-first century is a cautionary tale to scholars, because it reminds us how the reputation of an author-and the physical properties of her text - may be shaped not only by her gender and the literary standards of subsequent generations, but also by her editors' personal tastes and needs, and the motivations of the scholars and readers of subsequent generations who use those texts for their own purposes.

The widespread erasure of early modern women's texts from the literary canon is, at this point, undisputed; but the reasons for the loss of women's writing are still open to debate. Early feminist literary scholars from the 1980's tended to present the dismissal of women writers as a masculinist academic conspiracy to deprive women of their righteous foremothers. In 1993, Margaret Ezell presented a more measured view of the goals of text recovery, insisting that attention be paid to women-authored texts which had been previously "excluded or obscured" (2) because they didn't fit into the dominant feminist image of "women's literature." Subsequent authors of women's literary history have been even less doctrinaire, and more likely to focus on the ways in which myriad factors collaborated in the disregard of female-authored texts. Recent works by Paula R. Backscheider (2005), Betty Schellenberg (2005), Behrendt (2009) and Lavoie (2009), honor the work of earlier feminist critics in their desire to integrate less well-known works by eighteenth-century women writers into literary history, but they also take a broader view of the reasons for the earlier exclusion of these works. For these critics the intricacies of contemporary book production, the demands of the marketplace, trends in book reviewing, and even the current demands placed on twentieth- and twenty-first-century academics all play a role in the exclusion of "minor" female authors. Increasingly, there is a call for literary critics and historians to be "prepared to let go of gender as our fundamental interpretive category" (Schellenberg 182), and to look at the way in which these female-authored texts are part of a larger community of work which includes popular authors, private writing, and ephemera.

Although the subtitle of this paper emphasizes Trench's gender, I am not claiming that her erasure from literary history is part of a larger conspiracy to deprive female writers of their legacy. Rather, I believe that the story of her rise to fame, subsequent denigration, and final erasure reminds us of the highly personal and sometimes serendipitous factors which come into play in the creation of literary history. Sometimes whether or not an author's work survives is not (as my students say) "all about being a woman"; sometimes it has more to do with luck and the weird ways that circumstance and fashion collide. 
After the death of Trench's second husband in 1860, her papers passed into the hands of her third son, Richard Chenevix Trench, ${ }^{3}$ who was soon to become the Dean of Westminster. He immediately set about preparing an edited version of her diaries for the printing press. Part of his motivation for rushing to publish his mother's papers was doubtless his desire to take advantage of the current vogue for letters and memoirs "from the last century." As reviewers for The Dublin University Magazine testily remark,

certain it is that the rage for personal memoirs, growing like the dropsy with its own surfeit, has turned the printing press into one vast reservoir of old family papers of every kind . . . ere long every family which owns a dozen old letters hidden away for years in a musty old box, will doubtless hasten to prove its respectability by getting them published for the benefit of the world at large. ("Three Social Lights" 82)

For the most part, the upsurge in the publication of eighteenth-century memoirs reflected a Victorian hunger for details about the private lives of public figures and in books' somber bindings, many of these texts were proto-tabloid in their depiction of celebrities in awkward situations. The Dublin University Magazine review commented, "Readers of the fair sex, and some men of half-womanly natures, long to have a closer acquaintance with the man whose public deeds or writings they have learned to admire" ("Three Social Lights" 83). Richard Chenevix Trench knew that his mother's journals offered something irresistible to the less highminded ("womanly") members of the reading public: a detailed account of the bad behavior of the eighteenth century's ultimate celebrity-Admiral Lord Nelson-who was on an illicit junket with his consort, Lady Hamilton in October of 1800 when Trench happened to be staying in Dresden.

Trench's ${ }^{4}$ account of the time that she spent with the Nelson party was unusual for its unvarnished depiction of the less admirable aspects of the Admiral's behavior and for the downright meanness of her observations on Lady Hamilton. Trench's journal depicts Nelson as a self-absorbed, arrogant little man who is completely besotted by Emma Hamilton: "It is plain that Lord Nelson thinks of nothing but Lady Hamilton, who is totally occupied by the same object." Hamilton is described as "bold, forward, coarse, assuming, and vain" (197). Trench examines and criticizes virtually every aspect of Hamilton, from her hair "(which by-the-bye is never clean)" (199) through her waist "which is absolutely between her shoulders" (200) to her feet "which are hideous" (197). In addition to these acid-laced remarks, Trench's journal contains minute accounts of the week she spent in the company of the Nelson-Hamilton party, including descriptions of Lady Hamilton's “attitudes,” her singing, and the following "private” scene, which elicited a barrage of criticism in 1862:

[After dinner] Lady Hamilton, who declared she was passionately fond of champagne, took such a portion of it as astonished me. Lord Nelson was not behind-hand, calling more vociferously than usual for songs in his own praise, and, after many bumpers proposed the Queen of Naples, adding, "She is my Queen; she is Queen to the backbone, as to Queen Charlotte, she be d-d” Poor Mr. Elliot ... endeavored to stop the effusion of champagne, and effected it with some difficulty; but not till the Lord and Lady, or, as he calls them, Antony and Moll Cleopatra were pretty far gone. (202-03) 
Although Chenevix Trench edits the rest of his mother's writing with a heavy hand, he leaves most of the Nelson/Hamilton account intact except when he finds it necessary to intervene in passages where Trench's self-censorship is curiously mingled with a rowdy enthusiasm for risqué remarks. Trench happily records her host’s comparing Lady Hamilton to a sailor's prostitute, a "Jack's Trull," and also recounts Mr. Elliot's re-telling of the "story of Nel Gwin [sic]" in which the king's consort declares to the mob, "Gentlemen, I am not the popish W. I am the Protestant W." Trench has enough prudery to be unwilling to write out the word "Whore;" but her son finds even this edited version inappropriate for late-Victorian publication, and deletes both references. He also excises the passage in the "Journal” which shows Nelson being disrespectful to Britain's Queen Charlotte, completely omitting the line: "Queen Charlotte, she be d-d." from his version of the "Journal” (81).

When Chenevix Trench's edited version of his mother's travel journals was "printed, not published” in 1861 as “Journal Kept during a Visit to Germany in 1799, 1800," he claimed that his intention was to distribute the volumes only among family and "literary friends." However, on October 9, 1861, the London Times ran a long review article under the heading, "The Journal Edited by the Dean of Westminster" which made "allusion to a very curious volume" (8d). The Times printed extensive excerpts from the "Journal," devoting many columns to its account of the Hamilton/Nelson encounters. The Times stated that although the material was "private in the first instance ... the time has fully arrived in this case when they [these scenes] may be claimed as materials for historical portraiture” (8d).

In response, Nelson's Nephew, George Matcham wrote a letter of protest to the Times' editor and then privately published a pamphlet entitled "Notes on the Character of Admiral Lord Nelson in relation to the Journal of Mrs. St. George [Mrs. Trench].” In this work, Matcham describes Trench as a pathetic social climber of "singular self-complacency, love of attention and aspiration after the haute ton” (Hampshire MS 23M93/3/1/12). The pamphlet refutes the "Journal"'s account on every detail; from its description of Nelson's height, to his habitual use of salty language, and to his general comportment. The pamphlet ends with the ringing pronouncement, "The glory of Britain depends as much on the heroes she has produced, as on her wealth, her influence, her possessions" and it is the duty of every "true patriot and honourable man" to contribute to their luster and avoid all things which might "dim their fame; and diminish that high estimation of them" (14). The pamphlet had the effect of creating even more interest in Trench's journal, and provided an opening for contemporary periodicals to weigh in on the issue of how much of a celebrity's life should be made available to the public.

The next year, The Quarterly Review used the excuse of reviewing The Autobiography of Cornelia Knight to once again print Trench's Nelson/Hamilton entries, and to write in support of their publication: "the character of one of the real heroes of history should be thoroughly known-known in its weaknesses no less than its strength - is of very considerable importance indeed” (46). The Quarterly Review also defended Trench's reputation, absolving her of all desire to defame Nelson by reminding its readers that these observations, "were written down on the impression of the moment, and preserved for no purpose except that of communication to her own family. There is no suspicion of intended publication here” (46). 
The on-going "Nelson Controversy” whetted the appetite of the reading public for more material by Mrs. Trench. A review published in The Literary Examiner concluded by expressing "our regret at the shortness of this exquisitely graphic journal, and...our hope that the lost manuscript may be recovered" ("From the Literary Examiner" 550). The same hope was also expressed by Chenevix Trench's friends; Thomas Carlyle urged him: "If you find any more such manuscripts, be strongly tempted to print more,- - and let me share!” (Bromley 2). Chenevix Trench was willing to oblige; his biographer indicates that it was always the Dean's intention to print the "Journal” as "a preliminary test of literary opinion” (Bromley 148) and he immediately turned his hand to editing The Remains of Mrs. Richard Trench, which appeared in 1862.

Chenevix Trench opens The Remains of Mrs. Richard Trench: Selections from Her Journals, Letters, \& Other Papers, with a disclaimer concerning the condition of his sources: "the materials which came two years ago into my hands, are very incomplete ... the greater portion [of the journals of her earlier life] has perished, or . . . gone hopelessly astray . . . so it is also with the letters" (vi-vii). Yet, in spite of the incomplete nature of the materials before him, Chenevix Trench manages to eke out 520 pages of material, loosely arranged in chronological order and followed by a five page index listing places, events and "persons of interest" featured in the text. The Remains includes all of the text previously printed as the "Journal," with some very minor deletions to placate the critics who disapproved of Trench's depiction of Nelson. Every phrase which contains an implicit "damn" in the "Journal” is entirely deleted in The Remains. The rest of the book is something of a hodge-podge, with poems, memoranda, letters, poems, and essays jumbled together in rough chronological order. This makes it practically useless for the serious scholar, but the text itself is remarkably enjoyable for the casual reader, with, as Trench's early biographer, Frances A. Gerard says, "not one [moment] to shock or affront the most prudish reader" (135).

The reason that The Remains of Mrs. Richard Trench had nothing to offend a prudish reader was because its most prudish reader of all, the Dean of Westminster, was given a free hand in his role as editor. Well advanced into middle-age by the time he edited his mother's work, Chenevix Trench had already published extensively in a wide variety of fields: philology, theology, history, and translations of Spanish texts, as well as producing collections of his own poems and sermons. He is perhaps best remembered for his contributions to the shape and structure of the original Oxford English Dictionary, and this interest in orderliness and compression is evident in his editing of his mother's papers for publication. Furthermore, we are told by J. Bromley that he was an individual who cherished his dignity and possessed a temperament "which was not naturally buoyant" (152). It is to be expected that a son so different from his "sprightly" mother might (perhaps inadvertently) mold her Remains into something closer to his own image.

Also, we need to acknowledge the emotional pitfalls that even the staid Chenevix Trench must have encountered in editing the words of a woman whom he clearly idolized. As the Edinburgh Review remarked: "It required some courage to project, and much delicacy to execute as he has done, the design of bringing before the public the history of the mind and heart of one so near and dear to him" ("The Remains of the Late" 132). Certainly Chenevix Trench was motivated by his desire to present his mother in the way in which he believed that she wanted to be remembered: as a beautiful woman with "a charming personality, uniting, in an uncommon degree, cleverness with amiability ...” (Gerard 140). 
Finally, Trench's role as an editor must also have been affected by his considerable (though modestly disavowed) ambitions for rising within the Anglican Church. At the time that he was preparing his mother's works for publication, Richard Chenevix Trench was being considered for a number of Archbishop appointments in the British Isles. His public celebration of his witty, wise and morally irreproachable Irish-born mother may have well contributed to his elevation to the Archbishopric of Dublin in 1863. Given these three factors-Chenevix Trench's personality, his respect for his mother, and his ecclesiastical ambitions - it is not surprising that the 1862 Remains omits a number of incidents and anecdotes that may have seemed a bit too "worldly" for a beloved relative, or the mother of a future Anglican Archbishop.

Any time Trench's journals indicate that she has any familiarity (even secondhand) with undesirable, or disreputable elements, these passages are invariably deleted from The Remains. Chenevix Trench edits out references to his mother's accounts of the "licentiousness of private life and facility of divorces” (Hampshire MS 23M93/1/4) which she observes in Germany and removes the abundant evidence of her enthusiastic participation in that society.

Chenevix Trench also suppresses all of Trench's references to her many flirtations and romantic relationships. Trench was thirty-two at the time of her travels to Germany, and she had been living as a widow for ten years, keeping houses in Dublin and London, and renting accommodations at various British watering holes during "the season.” Both her letters and journals include extensive references to the many men who sought her hand (or her favors) right up until the time of her second marriage to Richard Trench in 1803. Although there is no indication that her reputation was ever compromised, there is a cool, sexually confident tone in these accounts which would have been at odds with the more rigid views of Victorian readers. For example, the published versions of her journals completely omit this April 17 entry:

Another declaration was made to me this morning, and I am not sorry the declarer leaves Vienna soon for though he is neither young nor handsome there is some thing about him that pleases me, and I might be induced unintentionally to make a fool of him. The Comte de Callenberg was the person, and his wife liked me almost as well. (122)

Chenevix Trench may have justified his omissions as "protecting” the names of those involved, but it is clear that the main reputation that he was protecting was his mother's — and, by extension, his own.

Among the Chenevix Trench's most striking deletions were those which excised his mother's relationship with Prince Adolphus, the seventh son of Britain's George III, who was acting as Regent in Hanover at the time of Trench's travels. In the review of Remains appearing in the Edinburgh Review, Richard Monckton Milnes, an intimate friend of Richard Chenevix Trench, intimates that "the charming widow made so deep an impression on the Prince that nothing but the stern provisions of the Royal Marriage Act debarred her from an alliance of the highest rank" (124). In her letters to her cousin, Sarah Tuite, Trench describes the time that she spent with the Prince, in rapturous but chaste terms: "I have tasted happiness-pure, innocent, and of which the recollection is as delightful as the enjoyment” (Austen-Leigh MS 23M93/1/4 262). Elsewhere, she compares her feelings for him to the sentiment of "culte" described by Madame de Stael: "which is not love because it feels no jealousy, and because it exacts nothing but which 
resembles love in being confined to one object, and in preserving the heart from every other impression” (Austen-Leigh MS 23M93/1/4 186-187).

In Chenevix Trench's version of their encounters, Prince Adolphus is merely another celebrity name to be dropped, and his mother only sees him socially at public dinners, balls, and an occasional morning visit. The actual manuscript of Trench's travel journal shows a much more extensive and intimate acquaintance. They begin with an evening visit: "We talked for two hours, and I find his conversation fluent, various and entertaining” (Austen-Leigh MS 23M93/1/4 21); and they progressed to taking long walks together, waltzing at balls, and taking "private tours" of some of the most exclusive homes in Hanover (including the Prince's own). Two weeks after their first meeting, Trench is writing: "My days are all marked with some fresh instance of attention or kindness. Prince Adolphus omits no opportunity of embellishing them. He usually calls every day in the morning or evening, and we sing duets with great perseverance ... ” (29). Of course, this entry is completely missing from Chenevix Trench's versions of the journal, as are Trench's notes of the many private dinners that she and the Prince share near the end of her stay in Hanover.

We learn from her manuscript that one of the reasons they begin to share intimate dinners, is because "my friends are now beginning to inform me of all the scandal of Hanover" (34) including information about Prince Adolphus’s long-time lover, Mme. De Bock, and the knowledge that "all eyes are fixed on the Prince, Madame de Bock, and me" (37) whenever they appear in public. The version presented by her son circumvents the scandal by claiming that Trench stays home during this period because "I have a little cold" (Remains10). Trench and the Prince part six weeks and six days after meeting, but continue to correspond ${ }^{6}$ during the rest of her time on the Continent. From her letters to Sarah Tuite, we learn that the pair traveled together back to England, a voyage that Trench describes in breathless detail: "I sat close to him-more than ever under his protection, from the idea of a danger which really existed-and neither of us spoke, but in monosyllables, in that low changed voice which darkness, stillness and novelty produce!” (Austen-Leigh MS 23M93/1/4 262b). Although the relationship with the Prince is perhaps the greatest omission made by Chenevix Trench in terms of its emotional significance to his mother, his editing of the writings from other stages of her life also reflect his need to present her in the best possible light.

Another area in which Chenevix Trench intervenes to control his mother's self-representation is in the private writings which relate to Trench’s loss of her young son Frederick in 1806.

Although Chenevix Trench does include some of this material in The Remains, he dramatically edits these passages, printing only seven pages of text drawn from the almost sixty pages of her Mourning Journal (Hampshire 23M93/13). Chenevix Trench says in his brief preface to this section, "The impression which this loss made, as will be seen by the many subsequent allusions to it, was profound and lasting” (199), but he does not present the passages that most fully represent Trench's anguish over her son's death. Chenevix Trench's need to depict his mother as emotionally controlled is evident in his subsequent suppression of any remarks she makes regarding her continued depression over the loss of her son. The original letters are full of passages about the "unpleasant and sorrowful period" following Frederick's death and her unsuccessful attempts to "lighten . . . the burden . . . [of her] cares" (Hampshire 23M93/23/54). 
The London Times identified the primary interest in these memoirs (beyond the scandal of seeing Nelson behaving badly) as nostalgic: "we salute her [Trench] as she sits, with tender respect of the time when our grandmothers were Graces, and bloomed as freshly as the blossoms of the old roses” ("The Remains of Mrs.” 9a). So, it seems that Chenevix Trench's own instincts regarding Victorian propriety had the immediate effect of making the text more popular and more highly regarded. But, ultimately Chenevix Trench's transformation of the passionate, worldly and sometimes irreverent private writing of Trench into the staid and proper The Remains of Mrs. Richard Trench, has played a significant role in her subsequent erasure from literary view. The published, public image of Trench is simultaneously so extensive (500+ pages), and yet so devoid of what is of most interest in her life, that it is not surprising that very few twentieth (or twenty-first) century scholars have bothered to access the mountains of Trench material that have been carefully preserved on two continents.

Without exception, the scholars who have returned to the "Journal" or The Remains, have been those who are primarily interested in Trench's account of the time she spent with the Nelson/Hamilton party. As the years have passed, and the reputations of both Nelson and Hamilton have been enhanced by increasingly sympathetic biographers, Trench's own reputation has suffered a proportionate decline. One of the earliest citations of Trench's journals is found in Walter Sydney Sichel's Memoirs of Emma, Lady Hamilton, published in 1891. Sichel invokes Trench's “Journal” account of the Dresden visit as "a stock passage in the diaries of a charming woman” (327). Six years later, in A.T. Mahan’s The Life of Nelson (1897), Trench is described as "a lady in London society, who viewed her [Lady Hamilton] possibly with something of the repugnant prejudice of a refined and cultivated woman" (i, 380) and whose "description and comments have been considered severe, and even prejudiced” (ii, 43). Still, Mahan defends the veracity of Trench's writing, noting that it is corroborated by other accounts: "those of the Mintos and Fitzharris” (ii, 43).

In contrast, twentieth century biographies of Nelson and Hamilton are filled with their own "repugnant prejudice” for Trench. In 1908, E. [Esther] Hallam Moorhouse, deals the public image of Mrs. Trench a blow from which it never recovers. Moorhouse introduces her quotations from Trench's “Journal” by saying they are "so unflattering and-perhaps by reason of their sharpness - so well known” (263). She refers sarcastically to "the immaculate Mr. Elliot and Mrs. St. George [Trench]" and condemns Trench's account as "tinged with malice and conscious superiority, and redeemed by no grace of kindly restraint” (267, 264). Moorhouse closes her chapter with this lecture:

Had Mrs. St. George [Trench] chosen to censure the moral wrong of which Nelson and Lady Hamilton were guilty, the outrage to the feelings of the silent wife waiting in England while they paraded the Continent, there could have been nothing but agreement with her condemnation. But it was external things she criticized: the defects of manner and taste of a great and worn-out seaman, who was childishly vain and very slow to think that people could be judging him unkindly, and of a woman whose heart was on all occasions better than her breeding. (267-68) 
Trench's twentieth century reputation continued to decline as she was represented with increasing vitriol by a parade of Nelson and Hamilton scholars. Hugh Tours, writing in The Life and Letters of Emma Hamilton (1963), indicates that Trench "did not approve of what she called 'the Nelson party"” and that she wrote with "a cynical wit,” but he also remarks that "her scathing comments have an unpleasant ring of truth about them” (155). Two books written seven years later, Jack Russell's Nelson and the Hamiltons, and Mollie Hardwicke's Emma, Lady Hamilton are also openly disapproving of Trench, but seem less familiar with her writing. Russell misidentifies Trench's nationality and accuses her of gossip mongering, while Hardwicke describes Trench as a xenophobic, anti-Semitic "prig of the first water" (71) with a personal grudge against Emma Hamilton.

Twenty-first century scholars continue Russell and Hardwicke's movement away from Trench's actual texts. In her otherwise excellent re-consideration of Emma Hamilton found in Women, Nationalism, and the Romantic Stage, Betsy Bolton does not list the "Journal" or Remains as a source, but instead relies on E. Hallam Moorhouse's assessment of Trench. Even worse is Julie Peakman's Emma Hamilton which muddles Hugh Tours' account, assigning statements made by Mr. Elliot to Mrs. Trench. It seems that following her denigration at the hands of the scholars and biographers of the twentieth century, Trench has entered the twenty-first century primarily as a caricature of social disapproval, a nay-saying prude whose own lively and self-deprecatory humor has been largely erased in the service of the reclamation of Emma Hamilton.

In his efforts to give his mother an image which was in keeping with Victorian standards (and to further his own ambitions for a future Bishopric), Richard Chenevix Trench eliminated any elements of her writing which would have offended nineteenth century sensibilities. As a result, the Remains downplay or delete Trench's somewhat wicked sense of humor, her familiarity with society's more risqué elements, her intense passion for her husbands, and her reoccurring bouts of depression following the loss of her son Frederick. Edited to Victorian specifications, Trench is lovely but bland, and her work offers little to intrigue the twenty-first century reader (or scholar). With so much to read in the expanding cannon of early female authors, it is not surprising that no contemporary scholar has chosen to seek out (let alone read) the writings of "a prig of the first water" whose primary claim to fame was tattling on Nelson in his cups and being mean to Emma Hamilton. For Trench, the cost of her proverbial fifteen minutes of Victorian fame has turned out to be a hundred and fifty years of subsequent obscurity.

And yet, as intriguing as it may be, the loss, recovery, and erasure of Trench, is not the end of the story. Although Chenevix Trench may not have served his mother's legacy well with his heavyhanded editing of her writings, he is not ultimately the villain of this piece. Chenevix Trench may have felt many of his mother's adventures and opinions to be in need of suppression, but he did not indulge in a Cassandra Austen-like purging of her papers. And, although it may have led to her being reviled and dismissed by twentieth and twenty-first century scholars, the Nelson controversy brought Trench sufficient fame during the fifty years after her death to insure that her private writings would be valued by her descendents and eventually deemed worthy of preservation in the Hampshire Record Office. Thanks to the chain of events outlined above, Trench in all her lively, histrionic, and, yes, sometimes acerbic, glory is available today for yet another re-discovery by anyone who has very good eyesight, and a lot of time to spend in Winchester. 
Works Cited

Austen-Leigh. Typescript of journals and letters. TS Hampshire Record Office, Winchester. Ref. MS 23M93/1/4.

Rev. of “Autobiography of Miss Cornelia Knight,” by Cornelia Knight. The Quarterly Review 3 (1862): 41-72. Print.

Backscheider, Paula R. Eighteenth Century Women Poets and Their Poetry: Inventing Agency, Inventing Genre. Baltimore: Johns Hopkins UP, 2005. Print.

Behrendt, Stephen C. British Women Poets and the Romantic Writing Community. Baltimore: Johns Hopkins UP, 2009. Print.

Bolton, Betsy. Women, Nationalism, and the Romantic Stage: Theatre and Politics in Britain, 1780-1800. New York: Cambridge UP, 2001. Print.

Bromley, J. The Man of Ten Talents: A Portrait of Richard Chenevix Trench, 1807-86, Philologist, Poet, Theologian, Archbishop. London: SPCK, 1959. Print.

Ezell, Margaret J.M. Writing Women’s Literary History. Baltimore: Johns Hopkins UP, 1993. Print.

"From The Literary Examiner: Journal Kept during a Visit to Germany in 1799-1800.” Rev. of Journal Kept during a Visit to Germany in 1799-1800. Littell's Living Age. Third Series. 70.900 (31 Aug. 1861). Boston: Littell, Son, 547-50. Print.

Gerard, Frances A. “Melesina Chenevix Trench (1768-1827).” Some Fair Hibernians: Being a Supplementary Volume to Some Celebrated Irish Beauties of the Last Century. London: Wade \& Downey, 1897. 111-40. Print.

Hardwicke, Mollie. Emma, Lady Hamilton. New York: Holt, Rinehart and Winston, 1969. Print.

“The Journal Edited by the Dean of Westminster.” London Times 9 Oct. 1861. 8d. Print.

Lavoie, Chantel M. Collecting Women: Poetry and Lives, 1700-1780. Lewisburg, PA: Bucknell UP, 2009. Print.

Mahan, A.T. The Life of Nelson. London: Sampson, Low, Marston, 1897. Print.

Matcham, George. "Notes on the Character of Admiral Lord Nelson in Relation to the Journal of Mrs. St. George.” London: Ridgway, 1861. MS. Hampshire Record Office, Winchester. MS 23M93/3/1/12. 
Moorhouse, E. Hallam. Nelson’s Lady Hamilton. London: Methuen, 1908.

Peakman, Julie. Emma Hamilton. London: Haus, 2005. Print.

Rev. of “The Remains of Mrs. Richard Trench.” London Times 21 Apr. 1862: 21a.

Rev. of "The Remains of the Late Mrs. Richard Trench.” The Edinburgh Review. 116 (JulyOct. 1862) American edn. New York: Scott, 1862:120-32.

Russell, Jack. Nelson and the Hamiltons. New York: Simon and Schuster, 1969. Print.

Schellenberg, Betty A. The Professionalization of Women Writers in Eighteenth-Century Britain. Cambridge: Cambridge UP, 2005. Print. http://dx.doi.org/10.1017/CBO9780511597633

Sichel, Walter Sydney. Memoirs of Emma, Lady Hamilton. 1891. New York: Collier \& Son, 1910. Print.

“Three Social Lights of the Eighteenth Century” Dublin University Magazine 58 (July-Dec. 1861): 82-99. Print.

Tours, Hugh. The Life and Letters of Emma Hamilton. London: Victor Gollancz, 1963. Print.

Trench, Melesina. “Journal Kept During a Visit to Germany, in 1799, 1800.” Ed. Richard Chenevix Trench. London: Savill and Edwards, 1861. Print.

—. Laura's Dream, or, The Moonlanders. London: Hatchard, 1816. Print.

—. Mourning Journal. 1806-1808. MS. Hampshire Record Office, Winchester. Ref. 23M93/13.

-. The Remains of the Late Mrs. Richard Trench. Ed. Richard Chenevix Trench. London: Parker, Son, and Bourn, 1862. Print.

—. "Sonnet Written at Night after Returning from a Dance at Mrs. Bathurst's.” Trench, The Remains of the Late Mrs. Richard Trench. 367.

—. Thoughts of a Parent on Education. London: Parker, 1837. Print.

—. Travel Journals. MS. Hampshire Record Office, Winchester. Ref. 23/M93/1-5.

Trench, Richard Chenevix, Dean of Westminster, ed. The Remains of Mrs. Richard Trench: Selections from Her Journals, Letters, and Other Papers. By. Melesina Trench. London: Parker, Son, and Bourn, 1862. 
Archive Materials:

Austen-Leigh typescript of journals and letters. TS Hampshire Record Office, Winchester. Ref. MS 23M93/1/4.

Autograph draft autobiography. n.d. MS Hampshire Record Office, Winchester. Ref. 23M93/2/1.

Letterbook. 1814-1828.MS Hampshire Record Office, Winchester. Ref. 23M93/18.

Letters to second husband. 1805-1816.MS Hampshire Record Office, Winchester. Ref. 23M93/14/1/A.

Letters to Mary Leadbeater. Ballitore Papers, Osborn collection, Beinecke Rare Book and Manuscript Library, Yale U. OSB MSS 50.

Letters to Sal Tuite. 1795-1822.MS Hampshire Record Office, Winchester. Ref. 23M93/42/33.

Memoranda 1812. 1793-1812. Hampshire Record Office, Winchester. Ref. 23M93/8.

Mourning Journal. 1806-1808. MS Hampshire Record Office, Winchester. MS Ref. 23M93/13.

Travel Journals. MS Hampshire Record Office, Winchester. Ref. 23/M93/1-5. 


\section{Notes}

1. For a brief biographical overview, see my article "Melesina Chenevix St. George Trench.” The Female Spectator 10.2 (Summer 2006): 4-6. Print.

2. This unpublished manuscript is currently housed in the Hampshire Record Office in Winchester. It is listed as MS 23M93/13. For a full description of the text and its significance see my article, “A Long- Forgotten Sorrow: The Mourning Journal of Melesina Trench.” Eighteenth- Century Fiction 21:1 (Fall 2008): 153-77. Print.

3. When it became clear that their half-brother, Charles Manners St. George, would not father any children, the three surviving Trench sons (Francis, Richard and Phillip) took the name "Chenevix Trench" as they were expected to inherit the Chenevix properties.

4. In referring to the writings and opinions of Melesina Trench before 1803, I will continue to refer to her as "Trench," although she was actually still Mrs. St. George at this time. I feel justified in doing this since the writing was published under the name of "the late Mrs. Richard Trench,” and because it is simply less confusing to use a consistent surname.

5. Unless otherwise specified, all references to Trench ${ }^{\text {ee }}$ travel journals refer to the typescript prepared by her descendent, Arthur Richard Austen- Leigh in the early twentieth century. Although Austen-Leigh sometimes alters chronology in the service of narrative flow, his transcriptions are as scrupulously accurate as it is possible to be, given the physical challenges of the actual journals. His typescript can be found in the Hampshire Record office, listed as MS 23/M93/3/1-17.

6. According to Milnes, "it was only upon the subsequent marriage of Mrs. St. George to Mr. Trench, that the Duke returned her letters and her portrait by the hands of Lady Carysfort, intimating with great delicacy that he thought he had no longer the right to keep them” (124). These letters (and his to her) are lost. 